\title{
Does Pyrrhonism Have Practical or Epistemic Value?
}

\section{Introduction}

My purpose in this paper is to examine whether Pyrrhonian scepticism, as this stance is described in Sextus Empiricus's extant works, has practical or epistemic value. More precisely, I would like to consider whether the Pyrrhonist's suspension of judgment (epochē) and undisturbedness (ataraxia) can be deemed to be of practical or epistemic value. By "practical" value I mean both moral value and prudential value. Moral value refers to moral rightness and wrongness; prudential value to personal or social well-being. Hence, when I ask whether the Pyrrhonist's suspension and undisturbedness have practical value, I mean whether they make us behave in a manner that is morally right or wrong, and whether they allow us to attain those goals that would make it possible to live well. As for "epistemic" value, it basically refers to the values of attaining truth and avoiding error. Hence, when I ask whether the Pyrrhonist's suspension has epistemic value, I mean whether it allows us to attain truth and avoid error. My main focus will be the practical value of both suspension and undisturbedness, because this is the value that scholars of ancient philosophy critical of Pyrrhonism have emphasised. The reason for examining the epistemic value of suspension is that doing so will enable a fuller assessment of the significance of Pyrrhonism as a kind of philosophy, which is my primary concern.

I will begin by briefly describing the states of suspension and undisturbedness and their connection, and by succinctly considering some objections to the effect that, despite claiming to suspend judgment across the board, Pyrrhonists actually hold a number of beliefs. This will provide the necessary framework for the subsequent discussions. I will then critically engage with interpreters who have called into question the practical value of undisturbedness and suspension. Next, I will examine what the epistemic value of suspension might be. I will end by considering whether, from a contemporary vantage point, one must conclude that Pyrrhonism has no practical or epistemic value, and hence that it is of no philosophical interest. ${ }^{1}$

This paper is a substantially revised and expanded version of an article originally published in Dutch as "De praktische en epistemische waarde van het pyrronisme," Algemeen Nederlands Tijdschrift voor Wijsbegeerte 108 (2016): 73-98. For their comments, I would like to reiterate my thanks to the anonymous reviewer for that journal and to Jan Willem Wieland, and to express my gratitude to the anonymous reviewer for the present volume.

1 Sextus employs "sceptic" and "Pyrrhonist" (and their respective cognates) interchangeably. I will do the same. I will also follow him in using the term "dogmatist" to refer to anyone who makes as- 


\section{Suspension and Undisturbedness}

When someone with even a slight familiarity with ancient Pyrrhonism thinks of it, two notions invariably come to mind, namely, epoche and ataraxia. This is perfectly reasonable. Consider, for instance, the definition of scepticism that Sextus offers at the beginning of his best-known work, the Pyrrhonian Outlines:

The sceptical [way] is an ability to set up oppositions among things that appear and things that are thought in any way whatsoever, an ability from which we come, through the equipollence in the opposed objects and arguments, first to suspension of judgment and after that to undisturbedness (PH 1.8). ${ }^{2}$

At PH 1.10, Sextus defines equipollence or equal force (isostheneia) as "equality in respect of credibility and lack of credibility, so that none of the conflicting arguments takes precedence over any other as more credible” (cf. PH 1.190, 196, 202); suspension as "a standstill of the intellect owing to which we neither deny nor affirm anything” (cf. PH 1.192, 196); and undisturbedness as "lack of perturbation and calmness of soul." Undisturbedness is not only the mental state at which the Pyrrhonist has arrived after suspending judgment, but the goal that prompted the Pyrrhonist-tobe to engage in philosophical inquiry in the first place. Indeed, Sextus tells us that the hope of becoming undisturbed is the "causal principle" (i.e., the initial motivation) of the sceptical philosophy (PH 1.12), and that so far the Pyrrhonist's aim is both undisturbedness in matters of opinion and moderation of affection (metriopatheia) in those things that are unavoidable ( $\mathrm{PH} \mathrm{1.25,} \mathrm{30;} \mathrm{cf.} \mathrm{PH} \mathrm{1.18,} \mathrm{215;} \mathrm{3.235).} \mathrm{Ac-}$ cording to Sextus's description of the Pyrrhonist's philosophical itinerary ( $\mathrm{PH} 1.12$, 26, 29; cf. AM 1.6), the Pyrrhonist-to-be was disturbed by the variation (anōmalia) he found in both perceptual and intellectual appearances and was in a state of aporia as to which of them he should assent to. For instance, the same object appeared to him to have conflicting perceptual properties depending on different spatial and quantitative variables, or the same moral view appeared to him to be both convincing and unconvincing depending on the vantage point from which it was considered. To remove that state of disturbance, the Pyrrhonist undertook philosophical investigation in order to determine which appearances are true and which are false. However, he was unable to do this owing to the seeming equipollence of the conflicting appearances, and so he suspended judgment. To his surprise, by suspending judgment he attained the state of undisturbedness that he was seeking all along-there being thus a contrast between the way undisturbedness was initially expected to be at-

sertions about how things really are on the basis of what they regard as objective evidence and sound arguments.

2 References to Sextus's works are supplied in parenthesis in the body of the text, using the following abbreviations: PH (Pyrrhoniae Hypotyposes), AM (Adversus Mathematicos), and AD (Adversus Dogmaticos = AM 7-11). All translations are my own. 
tained and the way it was in fact finally attained. Sextus emphasises that undisturbedness has closely followed suspension of judgment by chance (PH 1.26, 29) and as a shadow follows a body (PH 1.29).

Sextus does not limit himself to reporting that undisturbedness has in fact followed suspension. In the first and third books of $\mathrm{PH}$, and above all in Against the Ethicists (AD 5 = AM 11), he also explains why holding beliefs about how things really are prevents one from becoming undisturbed, offering at the same time an account of how suspension leads to undisturbedness, and also to happiness. His explanation focuses exclusively on evaluative beliefs: the presence of the things one believes to be good and of those one believes to be bad produces perturbation. For when a person lacks what he regards as good, on the one hand he intensely desires to obtain it and, on the other, he thinks he is persecuted by things naturally bad and restlessly tries to escape them. If he acquires what he considers to be good, he is nonetheless troubled both because he is irrationally and immoderately elated and because he is afraid of losing it (PH 1.27, 3.237, 277; AD 5.116-17, 146). For this reason, even when he is not directly disturbed by the presence of those things he deems to be bad, he continues to be troubled by his constantly guarding against them (AD 5.117, 129). In addition, those who believe that things are by nature good or bad are unhappy or can never attain happiness (AD 5.111, 113, 118, 130,144) inasmuch as "all unhappiness occurs because of some disturbance" (AD 5.112; cf. 141). Unlike the belief that things are by nature good or bad, suspension of judgment on the matter makes it possible to attain undisturbedness and happiness, and hence to lead a satisfactory life ( $\mathrm{PH}$ 1.28; AD 5.111, 144, 160, 168; see also PH 3.235; AD 5.147, 150), for those who suspend judgment "neither avoid nor pursue anything intensely" (PH 1.28). It should be noted that Sextus remarks that undisturbedness supervenes upon suspension of judgment about all things (PH 1.31, 205; AD 5.144; cf. AD 5.160, 168), which means that the attainment of undisturbedness has so far occurred only when the sceptic has suspended judgment about all the matters he has investigated-both those that concern values and those that do not. The sceptic cannot of course rule out the possibility that others will attain undisturbedness by suspending judgment only about some beliefs, but given his past experience, it appears to him that undisturbedness will be attained only when complete suspension is adopted. ${ }^{3}$

Despite what Sextus says in some of the passages just referred to, the Pyrrhonist is not free from all disturbance and hence cannot attain complete happiness, since not all disturbance is due to the intense pursuit of the things considered as good and the intense avoidance of the things considered as bad. For the Pyrrhonist is disturbed by certain things that impose themselves upon him, such as thirst and hunger (PH

3 I have elsewhere argued that, in Sextus's account of Pyrrhonism, one can identify three distinct causes of disturbance concerning matters of opinion and that the holding of evaluative beliefs is the ultimate source of doxastic disturbance by reference to which the other two can be explained. See Diego Machuca, “Sources of Doxastic Disturbance in Sextus Empiricus," Oxford Studies in Ancient Philosophy 56 (2019). 
1.29; AD 5.143, 148-50, 156-58; cf. PH 1.13, 24). Yet he is better off with regard to these unpleasant affections (pathe) than the dogmatist, since he does not experience the additional disturbance induced by the belief that such affections are by nature bad; it is precisely the absence of that belief that renders them moderate and more easily borne (PH 1.30, 3.235-36; AD 5.118, 150-55, 161; see also AD 5.128-29, 145, 156-60). The existence of those involuntary affections is the reason why Sextus says that moderation of affection in things unavoidable is, along with undisturbedness in matters of opinion, the sceptical aim.

It might be objected that, despite claiming to suspend judgment across the board, Sextus holds a number of beliefs about the nature of certain mental states as well as about the means for, and the hindrance to, the attainment of suspension and undisturbedness. First, undisturbedness is presented as the core component of human happiness and is hence deemed to be good or worthy of pursuit. Second, the state of disturbance, caused by the holding of beliefs, is considered as something bad or to be avoided. Third, there exists a causal link between undisturbedness and suspension, which makes the latter a desirable state. Fourth, the Pyrrhonist believes that the opposing arguments he uses are, because of their objective equipollence, an effective means to induce suspension.

For reasons of space, I will limit myself to making a few remarks in response to that general objection. First, the Pyrrhonist suspends judgment or makes no determinations about the intrinsic value of anything ( $\mathrm{PH} \mathrm{1.28,} \mathrm{163;} \mathrm{3.178,} \mathrm{182,} \mathrm{235),} \mathrm{and} \mathrm{hence}$ he does not believe that undisturbedness is objectively good or worthy of pursuit, and that disturbance is objectively bad or to be avoided. Rather, these two states appear to him to be, respectively, good and bad for himself and others, and hence when talking about them he is merely reporting on how things have so far appeared to him. At one point, Sextus explicitly observes that, whenever the Pyrrhonist says that some things are good and others bad, he is simply reporting on how they appear to him (AD 5.19-20).

Secondly, by saying that undisturbedness followed suspension by chance, Sextus intends to express his characteristic caution, which prevents him from asserting that things are by nature such that undisturbedness can only be reached by suspending judgment. Of course, he does not deny a necessary connection between them either. He is simply restricting himself to describing what has hitherto occurred to him and others, without making any assertions about the causal connection between those states. By likening the connection between suspension and undisturbedness to that of a body and its shadow, he is not being inconsistent. For one must not put the emphasis on the fact that a shadow always and necessarily follows a body when the body blocks light, but on the fact that in this situation there is a close connection between them. Sextus's intention is only to emphasise that up until now the 
sceptic's suspension has been closely accompanied by the state of undisturbedness. ${ }^{4}$ Although the sceptic does not assert that suspension causes undisturbedness, given his past experience he has the expectation that undisturbedness will continue to follow upon his suspension of judgment about everything. And if undisturbedness remains an aim he hopes to achieve, this will be a motivation for suspending judgment. The same considerations apply to the connection between the holding of beliefs and the state of disturbance: the sceptic only reports on his own experience.

Thirdly, Sextus does not believe that the arguments he has so far examined are objectively equipollent or equally credible, but only reports that they appear so to him (PH 1.196, 203). He employs certain types of arguments not because he can assure us that there is a necessary connection between them and suspension, but simply because those arguments have thus far been successful in inducing this state in himself and others. But this would be only a part of his response, given that, at $\mathrm{PH}$ 3.280-81, he tells us that the Pyrrhonist employs any therapeutic argument that makes it possible to induce suspension in his dogmatic patients. ${ }^{5}$ This shows that the Pyrrhonist does not restrict himself to utilising the arguments that have induced suspension in himself and his past patients, but may also use other arguments that have not proven similarly successful. Or-to put it another way-it shows that the arguments that have induced suspension in the Pyrrhonist and his past patients may not achieve the same results with future patients.

A final and related point concerns the following question: when the Pyrrhonist suspends judgment in the face of disagreements between equipollent positions, is the connection between equipollence and suspension to be interpreted as a requirement of rationality or as a merely psychological constraint? Some scholars have defended a rationalist interpretation according to which by suspending judgment the Pyrrhonist is abiding by the following principle or norm of rationality: one is rationally required to suspend judgment about $p$ in the face of a disagreement between views on $p$ that strike one as equipollent. Others have defended the psychological interpretation according to which suspension is the involuntary psychological effect of being confronted with rival views that appear to one to be equipollent. Given that the Pyrrhonist is a thinking being ( $\mathrm{PH}$ 1.24) who is hardwired to respond in specific ways, he is affected by the consideration of arguments pro and con $p$ and automatically reacts in a given way, even though he refrains from making assertions about both whether those arguments are sound and whether they are objectively equipollent. I will not enter here into the debate between the two interpretations, limiting

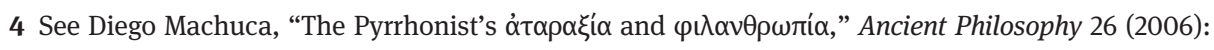
116.

5 On the Pyrrhonist's argumentative therapy, see Machuca, "The Pyrrhonist's $\alpha \dot{\tau} \alpha \rho \alpha \xi$ '́ $\alpha$ and

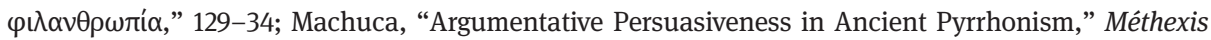
22 (2009): 102, 112; Machuca, "Pyrrhonian Argumentation: Therapy, Dialectic, and Inquiry," Apeiron 52 (2019): 199-221.
} 
myself to saying that I side with the psychological interpretation. ${ }^{6}$ As we will see in Section 4, the assessment of the epistemic value of suspension seems to partially depend on which interpretation is correct.

\section{The Practical Value of Suspension and Undisturbedness}

Whereas Sextus's explanation of how holding value beliefs produces disturbance may to a certain extent sound plausible from a contemporary vantage point, the references to undisturbedness and happiness sound alien to those who are today in the business of philosophy. The reason is that, in general, philosophy does not have much to do with our well-being anymore. Moreover, the claim that undisturbedness follows upon suspension may sound strange because we do not believe that we could ever get rid of much of what disturbs us in our lives by suspending judgment across the board. These and similar reasons no doubt explain why systematic discussions of Pyrrhonian scepticism in contemporary analytic philosophy have entirely ignored what Sextus says about undisturbedness, focusing for the most part on the epistemological implications of the so-called "Five Modes of Agrippa" and, to a lesser degree, on whether it is possible to eschew all beliefs and to act accordingly. It is nonetheless worthwhile to examine what practical value there may be in Pyrrhonian suspension and undisturbedness, because some scholars of ancient philosophy have called into question both their prudential and their moral value. I will review their criticisms and attempt to address them-at least in part.

One of the strongest and most common charges levelled in antiquity against both Academic and Pyrrhonian scepticism is the inactivity (apraxia) objection, of which there were various versions. According to that objection, the denial of all knowledge and the suspension of all judgment should be rejected because they make it impossible either to perform any action at all, or to act in certain ways (morally, sensibly, or rationally). ${ }^{7}$ Similar pragmatic responses to scepticism are found among interpreters of Pyrrhonism, some of whom have contested the prudential value of both suspension of judgment and undisturbedness. ${ }^{8}$ For instance, it has been argued that most

6 See Diego Machuca, "Pyrrhonism and the Law of Non-Contradiction," in Pyrrhonism in Ancient, Modern, and Contemporary Philosophy, ed. Diego Machuca (Dordrecht: Springer, 2011), sec. 5; Machuca, "Pyrrhonism, Inquiry, and Rationality," Elenchos 34 (2013): sec. 4.

7 I examine the various versions of the objection and the replies offered by Arcesilaus and Sextus in Machuca, "Scepticisme, apraxia et rationalité," in Les raisons du doute: études sur le scepticisme antique, eds. Diego Machuca and Stéphane Marchand (Paris: Classiques Garnier, 2019), 53-87.

8 The attempt to refute scepticism (of one kind or another) by focusing on its practical consequences is still today a common manoeuvre among both philosophers and ordinary people, who usually discard scepticism because its implications are disastrous, depressing, or immoral. Even in current discussions of the epistemic significance of disagreement, suspension of judgment is sometimes rejected 
theoretical puzzles, difficulties, or disagreements do not bring about anxiety but are rather exciting and enthralling'; that it is unreasonable or ridiculous to think that suspension can eliminate or mitigate the disturbance a person experiences or that suspension is a reliable recipe for tranquillity ${ }^{10}$; that belief in objective values produces a sense of security, not anxiety ${ }^{11}$; and that it is highly doubtful that the attainment of undisturbedness is either desirable or psychologically possible. ${ }^{12}$ If any of this were true, then the prudential value of suspension and undisturbedness would be undermined. For in those cases in which unresolved disagreements do not cause anxiety, there is nothing to be removed through suspension, while in those cases in which there is indeed anxiety concerning matters of belief, suspension is useless either because it is not efficacious in removing that anxiety or because it is simply impossible to achieve that goal given human beings' psychological makeup. And even if it were psychologically possible to attain the state of undisturbedness by suspending judgment, living an undisturbed life is not appealing or desirable because it would deprive us of all excitement.

In response, let me first note that the above criticisms overlook the fact that it seems to be one's own psychological makeup and one's personal history that determine to a considerable extent what causes anxiety in an individual, whether one regards an undisturbed life as liberating or depressing, and whether one is able to attain undisturbedness by suspending judgment or in any other way. ${ }^{13}$ For instance, some logicians and mathematicians seem to be distressed by their failure to find solutions to certain logical and mathematical paradoxes while others do not, even

because of its allegedly damaging practical effects. See Diego Machuca, "Conciliationism and the Menace of Scepticism,” Dialogue: Canadian Philosophical Review 54, no. 3 (September 2015): sec. 3. This shows-pace Suzanne Obdrzalek, "From Skepticism to Paralysis: The Apraxia Argument in Cicero's Academica," Ancient Philosophy 32 (2012): 388-90-that to reply to scepticism by pointing to its practical consequences is not foreign to contemporary epistemological discussions.

9 See Benson Mates, The Skeptic Way: Sextus Empiricus's Outlines of Pyrrhonism (New York: Oxford University Press, 1996), 63, 75-76; Jonathan Barnes, Introduction to Sextus Empiricus: Outlines of Scepticism, trans. Julia Annas and Jonathan Barnes, 2nd ed. (Cambridge: Cambridge University Press, 2000), $\mathrm{xxx}$-xxxi.

10 See Mates, The Skeptic Way, 63, 76-77; Barnes, Introduction, xxxi; Richard Bett, "Le scepticisme ancien est-il viable aujourd'hui?" in Les raisons du doute: études sur le scepticisme antique, eds. Diego Machuca and Stéphane Marchand (Paris: Classiques Garnier, 2019), 172.

11 See Julia Annas, "Doing without Objective Values: Ancient and Modern Strategies," in Companions to Ancient Thought IV: Ethics, ed. Stephen Everson (Cambridge: Cambridge University Press, 1998), 208, 213.

12 See Gisela Striker, "Historical Reflections on Classical Pyrrhonism and Neo-Pyrrhonism," in Pyrrhonian Skepticism, ed. Walter Sinnott-Armstrong (New York: Oxford University Press, 2004), 22; Striker, “Academics versus Pyrrhonists, Reconsidered," in The Cambridge Companion to Ancient Scepticism, ed. Richard Bett (Cambridge: Cambridge University Press, 2010), 196.

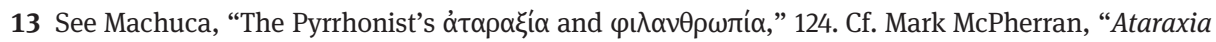
and Eudaimonia in Ancient Pyrrhonism: Is the Skeptic Really Happy?” Proceedings of the Boston Area Colloquium in Ancient Philosophy 5 (1989): 150. 
though all of them care about their research and believe that it has epistemic value, and perhaps even prudential value. Similarly, some people want to live a life of constant excitement, vertigo, and risk, and their heart would therefore sink at the prospects of a life characterised by the Pyrrhonist's undisturbedness; but others do prefer an undisturbed life. Moreover, some might even regard an undisturbed life as exciting. Finally, the person taking up the Pyrrhonian attitude may either enjoy a laidback and indifferent state of mind-being aware as he is of the unavoidable complexity of things and having, as it were, seen it all before-or else experience profound angst-due to the uncertainty caused by unresolved disagreements and the hesitation about what he is supposed to do in the absence of an epistemic criterion that would allow us to determine what is true and what is false. For instance, the realisation that one cannot establish whether there exist objective moral values might spare a person the anguish suffered by those who believe that an action they have performed is morally wrong, or else might lead that person to depression or distress. Whether, being a Pyrrhonist, one finds oneself in one or the other of these states seems to depend on one's personality or temperament. Consider the indisputable, albeit often overlooked, fact that people react in strikingly distinct ways both while and after facing extremely harsh situations. For example, while some people have been able to survive concentration camps or civil wars and then to rebuild their lives in remote countries after losing literally everything and without seeking revenge, many of us find their reactions extremely hard to understand and would most probably have been incapable of behaving in the same way. Consider also how some religious believers lead an anguished life despite their belief in the existence of a benevolent and provident god, while some agnostics lead a fulfilling life despite their suspension of judgment on the matter. I therefore do not think that there are sufficient grounds for regarding Sextus's report that some people were able to become undisturbed after suspending judgment as ridiculous or false, unless one believes that one is entitled to generalise one's own experience and dismiss a person's report of his experience when it is radically different. Suspension may or may not continue to work for the Pyrrhonist in the future and it may or may not work for other people; it is up to each individual to try it and see, so that there is no room for prejudices about its possible success. I do not mean to suggest that one must accept as true every testimony one hears, but only that one should be extremely cautious when discarding someone's report on his own experience. ${ }^{14} \mathrm{We}$ should keep in mind that Sextus does not intend to provide a recipe for becoming undisturbed or for attaining happiness, but only reports on what has so far occurred to him and others, and offers what appears to him as a tentative explanation of that experience. In sum, it does not seem possible to determine a priori whether suspen-

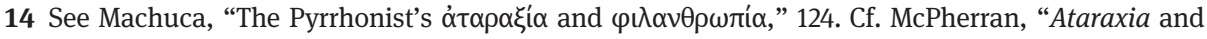
Eudaimonia in Ancient Pyrrhonism," 150, 171. 
sion and undisturbedness have any prudential value, i.e., whether they either contribute to or make possible the attainment of those goals we seek in order to live well.

Martha Nussbaum is the interpreter who has most vehemently criticised Pyrrhonism on account of its practical consequences, focusing on the moral and political value of suspension and undisturbedness. Her attack on Pyrrhonism in "Equilibrium: Scepticism and Immersion in Political Deliberation" is conducted by contrasting it with John Rawls's moral and political philosophy. ${ }^{15}$ Although she does not distinguish between them, Nussbaum in fact follows two different lines of argument: (1) one that calls attention to the supposedly harmful practical implications of Pyrrhonism ${ }^{16}$; and (2) one that calls attention either (a) to the Pyrrhonist's alleged inconsistency in believing in the value of undisturbedness and in being confident in the efficacy of his means to attain it, ${ }^{17}$ or (b) to his alleged failure to show the impossibility of the kind of justification that Rawls provided for our moral and political choices. ${ }^{18}$ These two lines of argument can be labelled, respectively, "pragmatic" and "epistemic." Note that, were the epistemic line of argument successful, there would be no need for the pragmatic: if the Pyrrhonist were inconsistent or did not succeed in undermining the epistemic justification of our moral and political beliefs and practices, then there would be no reason for worrying about the pragmatic consequences of adopting his sceptical outlook. The primary purpose of Nussbaum's essay, though, is to develop the pragmatic line of argument, most probably because she is shocked by what she takes to be the deeply damaging effects of Pyrrhonism and because she thinks there is a threatening revival of Pyrrhonism in certain postmodernist thinkers and in the popular part of our public culture. ${ }^{19}$ I will refrain from addressing here the epistemic line of argument mainly because I am particularly interested in Nussbaum's pragmatic line of argument, but also because I have dealt with the kind of inconsistency she ascribes to the Pyrrhonist in the previous section and elsewhere ${ }^{20}$ and because I think she simply underestimates the sceptical challenge that disagree-

15 Martha Nussbaum, "Equilibrium: Scepticism and Immersion in Political Deliberation," in Ancient Scepticism and the Sceptical Tradition (Acta Philosophica Fennica 66), ed. Juha Sihvola (Helsinki: Societas Philosophica Fennica, 2000), 171-97.

16 Nussbaum, 191-94.

17 Nussbaum, 189-92.

18 Nussbaum, 183-87.

19 In previous work, Nussbaum focused at greater length on the epistemic line of argument. See Martha Nussbaum, "Skeptic Purgatives: Disturbance and the Life without Belief," in The Therapy of Desire: Theory and Practice in Hellenistic Ethics (Princeton: Princeton University Press, 1994), 300-306; Nussbaum, "Skepticism about Practical Reason in Literature and the Law," Harvard Law Review 107 (1994): 733-36. Although Nussbaum also developed the pragmatic line of argument (see "Skeptic Purgatives,” 313-15; "Skepticism about Practical Reason,” 737-39, 742), she nonetheless saw some practical benefits in adopting the Pyrrhonian outlook (see "Skeptic Purgatives," 313; “Skepticism about Practical Reason,” 738, 742). In “Skepticism about Practical Reason," she discusses at greater length the views of those she regards as the contemporary counterparts of ancient Pyrrhonism.

20 See Machuca, “The Pyrrhonist’s $\alpha \tau \alpha \rho \alpha \xi^{\prime} \alpha$ and $\varphi \iota \lambda \alpha v \theta \rho \omega \pi i \alpha, ” 115-23,132-33$. 
ment poses to the task of epistemically justifying our moral and political beliefs and practices.

Nussbaum claims that Pyrrhonism is both "morally and politically pernicious."21 The Pyrrhonist's denial of the possibility of reaching a consensus among rival positions and his loss of commitment to normative beliefs are the sort of views that made the rise of Nazism possible and that could enable the recurrence of something similar. The reason is that, for the Pyrrhonist, the choice of a political regime cannot be based on reason, but only on the play of forces. She expresses a worry common among anti-sceptics:

[A] person who sees himself and his political life as simply a space in which forces play themselves out cannot be relied on for the same committed behaviour we can demand from a person who sees justice as possible and worthy of profound commitment and sacrifice. A person who views every claim as having its equally powerful counterclaim and his inclination to one side as mere antiquated habit is not likely to stick up for those habits in the way that someone will who believes that they are justifiable by a rational procedure. ${ }^{22}$

In addition, undisturbedness is not always desirable, for

the world in which we live is disturbing; disturbance is a rational response to it. And the person who is with good reason disturbed, and who sees her disturbance as well grounded, will not be satisfied, like the sceptic, by the removal of disturbance within her own person. ${ }^{23}$

She even goes as far as to affirm that Pyrrhonism is

profoundly selfish, indeed solipsistic ... seen as a program for philosophy in a needy and troubled world containing urgent human problems. ... If philosophy is only capable of making the individual practitioner feel calm, then Socrates's enemies would be right: philosophy is a dangerous form of self-indulgence, subversive of democracy, and its teachers are corrupters of the young. Fortunately, philosophy is capable of much more than that. ${ }^{24}$

Nussbaum also thinks that Pyrrhonism deprives us of part of what makes us human. For by suspending judgment, motivated by his desire for undisturbedness, the Pyrrhonist loses his normative commitments, and when these go, "something fundamental to humanity goes out with them, something that is integral to our ability to care for another and act on another's behalf." 25 She adds that

human beings are not only instinctual but also ethical creatures, who do care about getting things right and do commit themselves to views of the good, modifying their animal behavior accordingly. This means that the sceptic cannot straightforwardly claim to be allowing us to fol-

21 Nussbaum, “Equilibrium,” 171.

22 Nussbaum, 192-93. Cf. Annas, "Doing without Objective Values," 211-12.

23 Nussbaum, “Equilibrium,” 193.

24 Nussbaum, 194.

25 Nussbaum, 173. 
low our nature: he must admit that he is removing or curtailing something that is fundamental in the natures of most human beings. ${ }^{26}$

Thus, Nussbaum believes that the Pyrrhonist (i) is immoral, (ii) is unreliable, (iii) does not care about others, and (iv) removes something essential to our human nature. I will make six sets of remarks in reply to Nussbaum's four criticisms.

The first thing to be noted is that Nussbaum commits a petitio principii inasmuch as she takes for granted that about which the Pyrrhonist suspends judgment, namely, the existence of something that is objectively right or wrong. Instead of establishing the truth of the belief, called into question by the Pyrrhonist, that certain things are morally good or bad, Nussbaum begs the question by assuming the truth of that belief in her attack on Pyrrhonism. In her view, the world in which we live is disturbing because there are morally bad things that occur that cause indignation and disapproval-such as the rise of certain political regimes responsible for mass murderand so looking for personal undisturbedness is objectively wrong. This is why the Pyrrhonist is portrayed as selfish, solipsistic, politically subversive, and corruptive. These claims, even if they were true, have force only for those who are already moral realists; and I think it is acceptable to criticise the Pyrrhonist if one adopts such a point of view. But it should be borne in mind that, in doing so, one has not engaged the Pyrrhonist in philosophical debate, nor has one shown that he is mistaken in suspending judgment in the moral domain. Insofar as she does not discuss the Pyrrhonist's metaethical arguments, Nussbaum's pragmatic line of argument is dialectically ineffective.

Secondly, it is a mistake to claim that the Pyrrhonist is necessarily selfish, solipsistic, ${ }^{27}$ politically subversive, or corruptive, just as it is a mistake to claim that he is necessarily philanthropic (despite what Sextus says at PH 3.280-81), politically con-

26 Nussbaum, 191. Richard Bett makes a similar point when claiming that the Pyrrhonist's lack of moral commitments and the passivity shown in his practical decisions reveal that he is not an ethically engaged agent. See "How Ethical Can an Ancient Skeptic Be?" in Pyrrhonism in Ancient, Modern, and Contemporary Philosophy, ed. Diego Machuca (Dordrecht: Springer, 2011), 3-17. For this reason, he maintains, the sceptical life is not a life that people could reasonably welcome or to which they could aspire. It is also worth noting that a related objection has recently been raised by some interpreters on the basis of a version of the inactivity charge levelled by the Stoics against the Academic sceptics: even if the Pyrrhonist's scepticism does not condemn him to remain utterly inactive, his actions are not those of a rational agent, for he does not believe he can offer any epistemic reasons for his desires and his decisions, and so Pyrrhonism deprives us of the rationality distinctive of human beings. Proponents of this objection include Casey Perin, The Demands of Reason: An Essay on Pyrrhonian Scepticism (Oxford: Oxford University Press, 2010); Katja Vogt, "Scepticism and Action," in The Cambridge Companion to Ancient Scepticism, ed. Richard Bett (Cambridge: Cambridge University Press, 2010), 165-80; and Jan Willem Wieland, “Can Pyrrhonists Act Normally?” Philosophical Explorations 15, no. 3 (September 2012): 277-89. I have critically dealt with this objection in "Pyrrhonism, Inquiry, and Rationality," sec. 5, and in "Scepticisme, apraxia et rationalité," sec. 4.

27 Or individualistic, as Luciano Floridi has called him in Sextus Empiricus: The Transmission and Recovery of Pyrrhonism (New York: Oxford University Press, 2002$), 32$. 
servative or conformist (despite following the laws and customs of his community, $\mathrm{PH} 1.23-24),{ }^{28}$ or tolerant (despite the fact that he is unable to resolve disagreements and hence cannot reject any view on epistemic grounds). For whether the Pyrrhonist adopts one or the other of these attitudes depends on circumstantial factors, such as his psychological makeup, his upbringing, his education, his life experiences, and his socio-cultural context. ${ }^{29}$ None of these attitudes is necessarily entailed by the suspension of judgment or the adoption of what appears (to phainomenon) as the criterion of action (PH 1.21-24; AD 1.30 [= AM 7.30]). Insofar as he continues to suspend judgment across the board, the Pyrrhonist has no epistemic reasons either to embrace or to reject a given attitude, and so he will, as Nussbaum points out, let the play of forces drive him-a play of forces that nonetheless is not totally passive as it includes the exercise of the natural capability of thinking ( $\mathrm{PH} 1.24){ }^{30}$ But this means that nothing rules out the possibility that the Pyrrhonist may, for example, have been raised in a familial and social context in which philanthropy is deemed to be morally correct, and that the way things non-doxastically appear to him now is shaped by such a conception. By the same token, nothing rules out the possibility that he may be selfish and individualistic because of the upbringing he received or because of his life experiences. The same goes for the Pyrrhonist's alleged conservatism or conformism, for he may have been raised so as to oppose authority and the accepted ways of conducting oneself. ${ }^{31}$ Similarly, the fact that he cannot reject a given position on the basis of its being incorrect or epistemically unjustified does not entail that he must be tolerant. For his suspension does not of course require that he respects all the views held in his community because such respect is the morally correct attitude. He may resist certain positions simply because they constitute a practical hindrance to the way in which he lives or simply because they are emotionally disruptive. Now, Nussbaum herself recognises my point when she talks about the Pyrrhonist having an inclination towards a given attitude out of habit. She thinks that this makes him unreliable (a claim I address next), but the point is that she should accept that this does not make him necessarily selfish, solipsistic, politically subversive, or corruptive. It is clear that, from the point of view of moral realists, the Pyrrhonist's suspension does not have moral value insofar as it does not entail the

28 Bett writes about "the more general conformism of the skeptic," which he regards as an "unattractive feature" of the sceptic's stance ("How Ethical Can an Ancient Skeptic Be?" 11).

29 See Diego Machuca, Review of Luciano Floridi Sextus Empiricus: The Transmission and Recovery of Pyrrhonism, British Journal for the History of Philosophy 12, no. 2 (2004): 338-39; Machuca, "The Pyrrhonist's $\alpha \dot{\tau} \alpha \rho \alpha \xi \xi \alpha$ and $\varphi \iota \lambda \alpha v \theta \rho \omega \pi i \alpha, " 134-36$.

30 On the Pyrrhonist's extensive but non-normative use of reason, see Diego Machuca, "Argumentative Persuasiveness," 116-23; Machuca, "Pyrrhonism and the Law of Non-Contradiction," secs. 4 and 5; Machuca, "Pyrrhonism, Inquiry, and Rationality," sec. 4; Machuca, "Agrippan Pyrrhonism and the Challenge of Disagreement," Journal of Philosophical Research 40 (2015): sec. 3; Machuca, "Scepticisme, apraxia et rationalité," sec. 5.

31 Here I disagree with Bett, who claims that it is "unlikely that the skeptic will step far outside the status quo if ... that would be difficult or unpopular” ("How Ethical Can an Ancient Skeptic Be?" 12). 
adoption of those attitudes they regard as morally correct. But, once again, this is entirely different from claiming that he inevitably takes up attitudes that moral realists regard as morally incorrect. Someone might object that the Pyrrhonist's suspension lacks moral value all the same because, even though it does not preclude the adoption of an attitude of philanthropy, tolerance, or respect for accepted modes of conduct, such an adoption would not be based on the belief that these attitudes are morally correct. This may be so from the point of view of moral realists, but such an objection grants that the Pyrrhonist can conduct himself in a way that is not selfish, individualistic, politically subversive, or corruptive.

Thirdly, from a descriptive point of view, I am not sure that people with strong commitments are in general reliable, nor that they are more reliable than those who lack such commitments and let the play of forces drive them. This is so even in those few cases in which people have reflected on their commitments and believe that they are epistemically justified. Of all the religious believers and moral realists you know, how many are reliable because of their religious and moral commitments? It may be the case that someone is reliable precisely because he has strong commitments to certain principles and rules. But it seems clear that certain patterns of behaviour may be stronger when they have been unreflectively acquired in childhood than when they are the result of reflection, and in the former case they may be much harder to dislodge even if one came to the conclusion that they have no rational basis. It is no doubt possible that such patterns of behaviour are strengthened by a process of reflection and justification, but the important point is that this does not mean that they are not strong enough to confer reliability on the person in whom they have been inculcated independently of such a process.

Fourthly, as regards the claim that, by suspending judgment about moral commitments, the Pyrrhonist deprives us of part of our human nature, two remarks are in order. The first is that, pace Nussbaum, ${ }^{32}$ the Pyrrhonist does not completely deprive us of our emotions, for it does not appear to be the case that desiderative attitudes such as "anger, fear, jealousy, grief, envy, passionate love ... all rest ... upon belief" 33 and that "love, fear, grief" are based on "beliefs about worth." ${ }^{34}$ To be more precise, I do not think that such emotions depend necessarily on belief. For instance, do animals, which do seem to experience anger, fear, grief, and affection, hold beliefs? Also, granting that a two-year-old is capable of loving his mother, does he hold the belief that his mother is worth love? And even if he does, does he love his mother because he holds that belief? Someone could object that, even if one granted that emotions can be experienced in the absence of beliefs, Sextus's ascription of the state of undisturbedness to the Pyrrhonist indicates that he seeks to remove all emotions. One could reply by noting that, as we saw in the previous section,

32 Nussbaum, “Skeptic Purgatives,” 313-14; Nussbaum, “Skepticism about Practical Reason,” 737.

33 Nussbaum, "Skeptic Purgatives,” 313.

34 Nussbaum, "Skepticism about Practical Reason," 737. 
one part of the twofold goal of scepticism is the moderation of affection in things that are unavoidable, and by arguing that, among the affections in question, Sextus includes certain emotions. However, the examples he gives of unavoidable affections are always of a perceptual and physical kind: the feelings of cold and heat, thirst and hunger ( $\mathrm{PH}$ 1.13, 24, 29, 238; $\mathrm{AD}$ 5.143, 149, 152), pain and pleasure (AD 5.143, $150,159)$-where these seem to be understood exclusively in a physical way-and the fact of having a fever (AD 5.156); he also speaks more generally of the way one is affected perceptually ( $\mathrm{PH}$ 3.236; AD 5.148). I nonetheless think that, when Sextus speaks of the Pyrrhonist acting without opinions in accordance with the laws and customs of his community (PH 1.17, 23-24, 231, 237; AD 3.49, 5.166), there is an emotional component in the non-doxastic appearances he has by virtue of those social norms. Note that Sextus points out that the Pyrrhonist, proceeding in accordance with traditional laws and customs, accepts that piety is good and impiety bad (PH 1.24), and that he will choose one course of action and avoid the other if compelled by a tyrant to do some unspeakable deed (AD 5.166). It seems clear to me that this implies that impious actions induce a negative emotion and corresponding reaction in a Pyrrhonist who belongs to a given socio-cultural context. Similarly, if that Pyrrhonist witnessed what moral realists regard as an unspeakable or forbidden deed, he might automatically experience a negative emotion that would trigger a gut reaction: for instance, if faced with an act of rape, murder, or torture, he might experience a visceral response of repulsion and might do something to counter that act, even though he suspends judgment about whether such an act is objectively bad or to be avoided. If my interpretation is on the right track, then even after suspending judgment about whether anything is objectively good or bad, the Pyrrhonist still experiences positive or negative emotions when confronted with certain situations. ${ }^{35}$ Now, having moral emotions may be sufficient for us to be moral creatures. In this regard, note that, based on a number of studies in psychology, some moral psychologists have called into question the rationalist view that moral judgment is caused by a process of conscious reasoning or reflection, claiming instead that it is primarily and directly caused by moral intuitions and emotions. For example, according to the social intuitionist model defended by Jonathan Haidt, moral judgment is in general the result of intuitions-i.e., quick, automatic, effortless, and affectively laden evaluations-and moral action co-varies more with moral emotion than with moral reasoning. In his view, moral reasoning is usually nothing but an ex post facto process in which one seeks arguments that will justify an already-made judgment with the aim of influencing the intuitions and actions of others. ${ }^{36}$

35 For more on this issue, see McPherran, "Ataraxia and Eudaimonia in Ancient Pyrrhonism," 144,

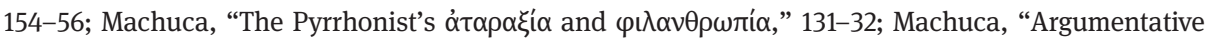
Persuasiveness," 123; Machuca, "Scepticisme, apraxia et rationalité," sec. 4.

36 See Jonathan Haidt, "The Emotional Dog and Its Rational Tail: A Social Intuitionist Approach to Moral Judgment,” Psychological Review 108, no. 4 (October 2001): 814-34; Thalia Wheatley and Jon- 
My second remark regarding Nussbaum's claim that the Pyrrhonist removes something that is fundamental in the nature of most human beings is that this would be a problem only provided that the thing removed is unquestionably good. Given that it is clear that Nussbaum thinks that the item removed is morally good, I should repeat here my remark that Nussbaum assumes what she should prove when arguing against the Pyrrhonist: removing something that is deemed to be good by the moral realist is not a problem for the Pyrrhonist inasmuch as he suspends judgment about whether anything is objectively good or bad. But setting the question of moral goodness aside, a present-day Pyrrhonist could point out that not everyone agrees on the instrumental goodness or usefulness of morality, as is shown, for instance, by the contemporary metaethical disagreement on this issue. Moral error theorists maintain either that all positive moral judgments are false because there are no objective moral properties, ${ }^{37}$ or that they are all neither true nor false because the moral facts they presuppose do not exist. ${ }^{38}$ However, among them there is a disagreement between moral fictionalists and moral abolitionists. The former claim that morality produces practical benefits (for example, personal happiness or political stability), and so that we should continue to make moral utterances and have moral thoughts, while at the same time refraining from asserting such utterances and believing such thoughts. That is, even though moral realism is false, we should maintain the fiction that it is true. ${ }^{39}$ One could argue that moral fictionalists think that morality is instrumentally good in that it is an effective means to attain certain goals we seek. Moral abolitionists, by contrast, contend that morality causes more suffering than it prevents, and that it is therefore desirable and useful to abandon moral language and thinking altogether. ${ }^{40}$

Fifthly, and in connection with my previous remarks on the Pyrrhonist's emotions, the claim that his suspension prevents him from properly caring about others overlooks the fact that whether one cares about someone or something seems to depend to a considerable extent on one's emotions rather than on one's beliefs. A mother who instinctively reacts to save her child from danger does not say to herself that she takes it to be true that she is morally obliged to save her child or that her child is worth saving; in fact, she may not have formed those beliefs at all and might never form them. You likely care about the well-being of your parents, your siblings, your children, your friends, or your spouse without having acquired the belief that you have the moral obligation to care about them or the belief that they are worth your care. Moreover, even though in some cases one concludes that one should

athan Haidt, "Hypnotic Disgust Makes Moral Judgments More Severe," Psychological Science 16, no. 10 (October 2005): 780-84.

37 See John Leslie Mackie, Ethics: Inventing Right and Wrong (Harmondsworth: Penguin, 1977).

38 See Richard Joyce, The Myth of Morality (Cambridge: Cambridge University Press, 2001).

39 See Joyce, The Myth of Morality.

40 See Richard Garner, “Abolishing Morality,” in A World without Values: Essays on John Mackie’s Moral Error Theory, eds. Richard Joyce and Simon Kirchin (Dordrecht: Springer, 2010), 217-33. 
not be concerned about what might befall them, one will very likely be concerned all the same. Hence, the holding of beliefs does not seem to be a conditio sine qua non for loving your child, being concerned about your dog's well-being, or caring about the result of a soccer match. As I argued above, it seems clear that the Pyrrhonist's suspension does not do away with such emotions. Hence, I think that Julia Annas is mistaken when she claims that the Pyrrhonist cannot be concerned about others' physical and emotional problems, ${ }^{41}$ i.e., their "mundane problems like toothache, poverty or unrequited love," because "these could only bother him if he believed that these were bad things, which of course he does not." ${ }^{42}$ In her view, the Pyrrhonist can only be bothered by others' intellectual problems, i.e., by their holding of beliefs, because that is what he seeks to cure by means of his argumentative therapy, which is motivated by a philanthropic attitude (PH 3.280-81). If so, he could not be concerned about the well-being of another full-blown Pyrrhonist. According to the deflationary interpretation ${ }^{43}$ to which I referred in my second set of remarks, neither philanthropy nor the therapeutic use of arguments should be viewed as defining features of Pyrrhonism: whether the Pyrrhonist is philanthropic or seeks to cure others of their dogmatism by means of argument will depend on circumstantial factors. But then one can likewise argue that nothing rules out the possibility that a Pyrrhonist may be emotionally troubled by the unavoidable problems of others. A Pyrrhonist who happens to be philanthropic may seek, by inducing suspension, to remove the disturbance apparently caused in the dogmatists by their holding of beliefs, but he may also seek to mitigate their unavoidable physical and emotional disturbances because he may be emotionally distressed by the unavoidable suffering of anyone-whether a dogmatist, a newly converted Pyrrhonist, or a veteran Pyrrhonist. Again, such distress will not be the result of the holding of beliefs, but part of the emotions that impose themselves on the Pyrrhonist to the extent that he is affected by those psychological and social factors that happen to influence him. Someone will no doubt complain, once more, that this does not make the Pyrrhonist very reliable given that his concern about others' problems of one kind or another will always be fortuitous or contingent. But I am not sure that this is different from the case of those who claim to care about others due to their beliefs or even reflective beliefs. For their holding the beliefs they hold seems to be dependent to a considerable extent on circumstantial factors. In addition, we see on a daily basis how many who claim to be moral realists or religious believers and to reject inequality and unfair suffering are entirely indifferent to those in need. Therefore, we should conclude ei-

41 Julia Annas, The Morality of Happiness (New York: Oxford University Press, 1993), 246-48, 353. 42 Annas, 246.

43 The reason I call my interpretation of certain aspects of Sextus's account of Pyrrhonism "deflationary" is simply that I do not take such aspects to be essential to this form of scepticism. My interpretation of the practical and epistemic value of Pyrrhonism is also deflationary inasmuch as, in my view, the Pyrrhonist does not think that his stance has either kind of value in an objective sense. 
ther that they are being disingenuous in expressing their normative commitments, or that belief does not ensure genuine concern for others.

Finally, I think it is important to make the probably obvious remark that, even if we grant that Pyrrhonism has no prudential or moral value, we should guard against mistaking pragmatic reasons for rejecting Pyrrhonism (or other forms of scepticism) for epistemic reasons. The fact that Pyrrhonism represents a hindrance to the attainment of certain goals one takes to be crucial to one's personal or social life does not prove that Pyrrhonism is incoherent or false. To do so, one has to examine whether there are epistemic reasons for rejecting Pyrrhonism, and if one cannot find any, then one should be prepared to accept the pragmatic consequences of our inability to refute it, even if they are appalling. At least those who are in the business of philosophy should swallow their fear and follow where the arguments lead.

I should emphasise that my aim has not been to defend the Pyrrhonist from the charge of immorality in the sense of showing that he necessarily conducts himself in a moral way, for whether he behaves morally or immorally from the point of view of non-Pyrrhonists depends on a number of fortuitous factors. Nor have I attempted to show that Pyrrhonism is a desirable or attractive philosophy inasmuch as it would contribute to our well-being, for whether one finds it so will depend, to a considerable extent, on contingent psychological factors. My aim has instead been to dispel certain serious misunderstandings regarding the Pyrrhonian stance. ${ }^{44}$

\section{The Epistemic Value of Suspension}

What about the epistemic value of the Pyrrhonist's suspension of judgment? What is its value concerning the goals of attaining truth and avoiding error? The answer seems to depend in part on whose vantage point one adopts and in part on how one interprets the connection between equipollence and suspension.

Let me address the second point first. As we saw in Section 2, such a connection can be interpreted either as a requirement of rationality or as a merely psychological constraint. If the Pyrrhonist's reason for withholding assent whenever confronted with conflicting views on $p$ that strike him as equipollent were a commitment on his part to investigating truth by applying the requirements of rationality, then the

\footnotetext{
44 For other replies to the charge that Pyrrhonism lacks practical value that somewhat complement the arguments advanced in the present section, see John Christian Laursen, "Yes, Skeptics Can Live Their Skepticism and Cope with Tyranny as Well as Anyone," in Skepticism in Renaissance and PostRenaissance Thought, eds. José Maia Neto and Richard Popkin (Amherst, NY: Humanity Books, 2004), 201-23; Laursen, "The Moral Life of the Ancient Skeptics: Living in Accordance with Nature and Freedom from Disturbance," Bolletino della Società Filosofica Italiana 219 (2016): 5-22; and Emidio Spinelli, "Neither Philosophy nor Politics? The Ancient Pyrrhonian Approach to Everyday Life," in Skepticism and Political Thought in the Seventeenth and Eighteenth Centuries, eds. John Christian Laursen and Gianni Paganini (University of Toronto Press: Toronto, 2015), 17-35.
} 
epistemic value of his suspension would be clear. For, first, by refraining from adopting a view on $p$ in favour of which he does not have compelling evidence, the Pyrrhonist seeks to avoid error. Second, by remaining engaged in rationally driven inquiry, he keeps searching for further evidence that could tip the balance in favour of one of the rival views on $p$, which would bring him closer to the truth. If, by contrast, the psychological interpretation of the connection between equipollence and suspension were correct, it could be argued that Pyrrhonism does not have much to offer in terms of epistemic value. For although the Pyrrhonist is a thinking being who is hardwired to suspend judgment when confronted with arguments pro and con $p$ that strike him as equipollent, he refrains from making assertions about whether those arguments are sound, whether they are equipollent, and whether suspension is the correct rational response in the face of equipollent disagreement. The Pyrrhonist does suspend judgment, he does refrain from affirming that investigation of truth is doomed to failure, and he does keep on inquiring into the various subjects about which people hold beliefs. But although his suspension might make it possible to avoid error, he does not affirm that this is indeed the case and that the avoidance of error is therefore one of his reasons for suspending judgment. And although his ongoing inquiry might make it possible to find the truth, he makes no assertions about whether his inquiry is the correct means to search for truth. In line with my deflationary interpretation of Pyrrhonism, I think that the Pyrrhonist's continuing engagement in philosophical inquiry is to be explained by the influence of psychological and social factors, and that his suspension only entails that he cannot affirm or deny that truth can be found.

I think, however, that it is a mistake to claim that Pyrrhonism is of no epistemic value if the psychological interpretation is correct, a mistake that brings me to the first point mentioned above. For even if the Pyrrhonist himself refrains from affirming (or denying) the epistemic value of his suspension, this does not mean that the suspension he exercises lacks epistemic value from the vantage point of those nonPyrrhonists who are committed to the requirement of rationality according to which one should suspend judgment when confronted with a dispute one is unable to settle. From that vantage point, it could also be argued that the epistemic value of Pyrrhonian suspension consists in that it encourages or promotes the intellectual virtues of caution and humility, in two respects. First, the Pyrrhonist's suspension is a recognition of his inability to give his assent to any one of the parties to a given dispute, i.e., a recognition that he has so far been unable to settle the disagreements he has examined. He describes as arrogance, rashness, and self-satisfaction the attitudes of his rivals ${ }^{45}$ inasmuch as they hold fast to their views on $p$ without taking careful account of rival views on $p$ or even despite acknowledging the existence of widespread and entrenched disagreement over $p$. One could take the Pyrrhonian attitude to be a good antidote to jumping to conclusions and performing hasty actions. He lacks his

45 See, for example, PH 1.20, 90, 177, 3.235, 280-81. 
rivals' overconfidence in the correctness of their own opinions and the reliability of their cognitive powers. In this regard, it is perhaps worth mentioning some recent studies in psychology that show that unskilled people tend to suffer from "illusory superiority," rating their cognitive abilities as above average, whereas skilled people tend to suffer from "illusory inferiority," underestimating or underrating their cognitive abilities. ${ }^{46}$ One could argue that Pyrrhonian suspension would protect us from this kind of epistemic bias, faced as we are with the difficulty of determining from which sort of illusion we might be suffering. Second, Pyrrhonian investigation is characterised by open-mindedness inasmuch as the Pyrrhonist does not affirm (or deny) that the disagreements he has so far inspected are unresolvable in themselves, but carries on his philosophical inquiry into the disputed matters. In other words, the Pyrrhonist's past failure to discover the truth in those matters (if there is any) does not lead him to claim that the search for truth is doomed to failure. For he cannot rule out the possibility that, through further investigation, he might discover new evidence and arguments bearing on the disputed matters that will make it possible to adjudicate the disagreements.

Some people-probably most-might nonetheless regard the Pyrrhonist's acrossthe-board suspension as lacking any real epistemic value in that it pushes intellectual caution and humility to the extreme. They would argue that the Pyrrhonist actually manifests the vices of intellectual cowardice and of undue timidity in one's intellectual life. For although there are cases in which suspension is indeed rationally required by the equal force of the evidence and arguments in favour of each of the conflicting views, in most cases we do have strong epistemic reasons for preferring one of the views to the other(s). For this reason, they would also argue that the Pyrrhonist is intellectually dishonest when he claims that, in all the disagreements he has considered, the rival views strike him as equipollent. In response, it should be remarked that, aside from the fact that the objectors' own experience is different from the Pyrrhonist's, there seems to be no reason for suspecting that the latter is not sincere or truthful when reporting on what has happened to him up to this point. For it may indeed be the case that the Pyrrhonist has found himself in the state of being at a loss how to resolve all those disagreements he has examined up to this point. Hence, I do not think that the objectors can easily maintain that the Pyrrhonist is disingenuous, although they could perhaps still hold that, from their own non-sceptical point of view, he is intellectually cowardly and unduly timid in his philosophical investigations.

\footnotetext{
46 See, for example, Justin Kruger and David Dunning, "Unskilled and Unaware of It: How Difficulties in Recognizing One's Own Incompetence Lead to Inflated Self-Assessments," Journal of Personality and Social Psychology 77, no. 6 (December 1999): 1121-34; Joyce Ehrlinger, Kerri Johnson, Matthew Banner, David Dunning, and Justin Kruger, "Why the Unskilled Are Unaware: Further Explorations of (Absent) Self-Insight among the Incompetent," Organizational Behavior and Human Decision Processes 105, no. 1 (January 2008): 98-121.
} 


\section{Concluding Remarks}

Does the Pyrrhonist promise us that, if we suspend judgment across the board, we will become undisturbed regarding matters of opinion? No, he does not because he cannot. Does he promise us that, if we attain such a mental state, we will find it enjoyable and will even achieve a considerable degree of happiness or wellbeing? No, he does not because he cannot. Does he promise us that the person who suspends judgment across the board will act morally? No, he does not because he cannot. Does he affirm that suspension has epistemic value in that it allows us to attain truth and avoid error? No, he does not because he cannot. Does this all mean that suspension and undisturbedness have no practical or epistemic value for us and that reading Sextus is of no philosophical interest to us? I have already partially addressed this last question at the end of the previous section, but I would like to examine it further to conclude.

Someone might indeed argue that, if the Pyrrhonist has no doxastic commitment to the practical and the epistemic value of suspension and undisturbedness but only reports on the way things have appeared to him up to this point, then his whole enterprise will look pointless and he will hardly win new supporters. ${ }^{47}$ Moreover, one might wonder whether Sextus's writings are of any philosophical interest insofar as throughout them he is merely offering a personal testimony on what has so far happened to him (e.g., PH 1.4, 187-209). In reply, let me make two sets of remarks.

To begin with, even though the absence of assertions may lead many to reject Sextus's writings out of hand, nothing necessarily precludes one from finding them philosophically challenging and intriguing. For it is one thing how Sextus intends what he writes to be interpreted, and quite another how his readers react to his writings or what use they can make of his writings. For example, someone may believe that some of Sextus's arguments are sound and have significant philosophical implications. Also, even if one rejects his stance as too radical, one may still find it philosophically stimulating in that it challenges one to ponder more carefully problems concerning knowledge, justification, inquiry, disagreement, and action. ${ }^{48}$ This in fact explains why quite a number of contemporary epistemologists have engaged with the justificatory challenges posed by the Modes of Agrippa. To better illustrate my point, let me refer to Henri Estienne's experience with Pyrrhonism as described in the preface to his Latin rendering of PH published in $1562 .{ }^{49}$ In an autobiographical story of the genesis of the translation, he tells us that while afflicted by a quartan

47 Cf. Nussbaum "Skeptic Purgatives,” 303; Nussbaum, "Equilibrium,” 189; and McPherran, "Ataraxia and Eudaimonia in Ancient Pyrrhonism,” 139-40.

48 See Machuca, "Pyrrhonism, Inquiry, and Rationality," $210 n 14$.

49 I have used the complete French translation of the preface provided by Emmanuel Naya in "Traduire les Hypotyposes pyrrhoniennes: Henri Estienne entre la fièvre quarte et la folie chrétienne,” in Le scepticisme au XVI et au XVII , ed. Pierre-François Moreau (Paris: Albin Michel, 2001), 48-101. 
fever that was caused by an immoderate study of letters and that made him hate the very sight of books, he stumbled upon an incomplete and hasty translation of the main principles of the Pyrrhonian sect that he had made some time before. Its first reading immediately made him laugh-subsequent readings having the same effect-which in turn allowed him to overcome his exhaustion and reconciled him with the letters. By ridiculing the doctrines of the dogmatic authors the reading of whose works required so much intellectual effort, Sextus's work had a therapeutic effect on Estienne, who therefore found Pyrrhonism of practical value. But, in Estienne's view, it may also be of both practical and epistemic value to the dogmatists themselves inasmuch as it can render them humble by attacking the impudence and rashness of their assertions, and by allowing them to recognise their cognitive limitations and to accept that the only truth is that of Revelation. By adopting such a fideistic stance, Estienne took Pyrrhonism to be a remedy not only for the aversion to the study of letters people may experience after reading the dogmatists' works, but also for the disease of impiety that affects the latter. Given such a twofold therapeutic efficaciousness, Estienne decided to make PH available to those with no knowledge of Greek. Even though he recognises such a curative effect, he cautions us against abusing the sceptical critical attitude by calling into question not only the erroneous things said by the dogmatists but also those that are valuable, and despite observing at the outset that he has metamorphosed into a sceptic, he later remarks that he is not himself one and does not intend others to become sceptics. Although Estienne makes clear the fictive character of his autobiographical story, the benefits he found in a certain application of Pyrrhonism are to be taken seriously. Sextus would of course reject a fideistic use of Pyrrhonism on the grounds that those who made such a use would be doxastically committed to certain metaphysical and religious views. But the issue under consideration is whether Pyrrhonism could be of practical or epistemic value to someone who is not a Pyrrhonist, and hence who eschews some of his beliefs while retaining others. In general, the fideistic use made of Pyrrhonism in Renaissance and modern philosophy is a clear example of the practical and epistemic value it may have for non-sceptics.

Secondly, it might well occur that some will identify with Sextus's account of his own experience or will be deeply influenced by it. For it does not seem possible to establish a priori that Pyrrhonism is utterly unappealing as a philosophy. ${ }^{50}$ Whether that is the case depends on whether one values such attitudes as caution, openmindedness, questioning, and intellectual modesty; and, if one does, on whether one thinks those attitudes should be adopted across the board and on whether one thinks they are to be preferred to the sense of comfort or reassurance one may experience when confidently espousing, say, moral or religious beliefs. For instance, I know a scholar for whom the reading of Sextus's writings prompts the experience of "being blissful," in much the same way as does the reading of certain

50 See Machuca, “The Pyrrhonist’s $\alpha \tau \alpha \rho \alpha \xi^{\prime} \alpha$ and $\varphi \iota \lambda \alpha v \theta \rho \omega \pi i \alpha, ” 138$. 
Buddhist texts. Also, if you may forgive my being self-referential, I should point out that I have been reading Sextus and been interested in Pyrrhonism as a philosophy for almost twenty years. Despite the deflationary interpretation of the epistemic and practical value of Pyrrhonism that I have defended in this essay, I still find that form of scepticism captivating and thought-provoking. This is due to the fact that I identify both with the Pyrrhonist's experience of being at a loss how to resolve the entrenched and longstanding disagreements we encounter in philosophy, morality, politics, religion, and economics, and with his experience of finding oneself, whenever one carries the application of the logical and epistemological principles dictated by reason to the limit, in a situation of aporia in which such principles end up undermining themselves.

You may still think that Sextus is not offering much, and you are of course free to think so. But just keep in mind that others may disagree: the brand of Pyrrhonism presented in his writings played an important part in the philosophical scene of the Imperial age, had a tremendous impact on Renaissance and modern philosophy thanks to the rediscovery of those writings, and continues to be a topic of lively discussion among both ancient philosophy scholars and analytic epistemologists.

\section{Bibliography}

Annas, Julia. “Doing without Objective Values: Ancient and Modern Strategies." In Companions to Ancient Thought IV: Ethics, edited by Stephen Everson, 193-220. Cambridge: Cambridge University Press, 1998.

Annas, Julia. The Morality of Happiness. New York: Oxford University Press, 1993.

Barnes, Jonathan. Introduction to Sextus Empiricus: Outlines of Scepticism, translated by Julia Annas and Jonathan Barnes, xi-xxxi. 2nd ed. Cambridge: Cambridge University Press, 2000.

Bett, Richard. “How Ethical Can an Ancient Skeptic Be?” In Pyrrhonism in Ancient, Modern, and Contemporary Philosophy, edited by Diego Machuca, 3-17. Dordrecht: Springer, 2011.

Bett, Richard. “Le scepticisme ancien est-il viable aujourd'hui?” In Les raisons du doute: études sur le scepticisme antique, edited by Diego Machuca and Stéphane Marchand, 153-77. Paris: Classiques Garnier, 2019.

Ehrlinger, Joyce, Kerri Johnson, Matthew Banner, David Dunning, and Justin Kruger. "Why the Unskilled Are Unaware: Further Explorations of (Absent) Self-Insight among the Incompetent." Organizational Behavior and Human Decision Processes 105, no. 1 (January 2008): 98-121.

Floridi, Luciano. Sextus Empiricus: The Transmission and Recovery of Pyrrhonism. New York: Oxford University Press, 2002.

Garner, Richard. “Abolishing Morality.” In A World Without Values: Essays on John Mackie's Moral Error Theory, edited by Richard Joyce and Simon Kirchin, 217-233. Dordrecht: Springer, 2010.

Haidt, Jonathan. “The Emotional Dog and Its Rational Tail: A Social Intuitionist Approach to Moral Judgment.” Psychological Review 108, no. 4 (October 2001): 814-34.

Joyce, Richard. The Myth of Morality. Cambridge: Cambridge University Press, 2001.

Kruger, Justin and David Dunning. "Unskilled and Unaware of It: How Difficulties in Recognizing One’s Own Incompetence Lead to Inflated Self-Assessments." Journal of Personality and Social Psychology 77, no. 6 (December 1999): 1121-34. 
Laursen, John Christian. "The Moral Life of the Ancient Skeptics: Living in Accordance with Nature and Freedom from Disturbance." Bolletino della Società Filosofica Italiana 219 (2016): 5-22.

Laursen, John Christian. "Yes, Skeptics Can Live Their Skepticism and Cope with Tyranny as Well as Anyone." In Skepticism in Renaissance and Post-Renaissance Thought, edited by José Maia Neto and Richard Popkin, 201-23. Amherst, New York: Humanity Books, 2004.

Machuca, Diego. "Agrippan Pyrrhonism and the Challenge of Disagreement." Journal of Philosophical Research 40 (2015): 23-39.

Machuca, Diego. “Argumentative Persuasiveness in Ancient Pyrrhonism.” Méthexis 22 (2009): 10126.

Machuca, Diego. "Conciliationism and the Menace of Scepticism." Dialogue: Canadian Philosophical Review 54, no. 3 (September 2015): 469-88.

Machuca, Diego. "De praktische en epistemische waarde van het pyrronisme." Algemeen Nederlands Tijdschrift voor Wijsbegeerte 108 (2016): 73-98.

Machuca, Diego. "Pyrrhonian Argumentation: Therapy, Dialectic, and Inquiry." Apeiron 52 (2019): 199-221.

Machuca, Diego. "Pyrrhonism and the Law of Non-Contradiction." In Pyrrhonism in Ancient, Modern, and Contemporary Philosophy, edited by Diego Machuca, 51-77. Dordrecht: Springer, 2011.

Machuca, Diego. “Pyrrhonism, Inquiry, and Rationality.” Elenchos 34 (2013): 201-28.

Machuca, Diego. Review of Sextus Empiricus: The Transmission and Recovery of Pyrrhonism, by Luciano Floridi. British Journal for the History of Philosophy 12, no.2 (2004): 336-40.

Machuca, Diego. "Scepticisme, apraxia et rationalité." In Les raisons du doute: études sur le scepticisme antique, edited by Diego Machuca and Stéphane Marchand, 53-87. Paris: Classiques Garnier, 2019.

Machuca, Diego. "Sources of Doxastic Disturbance in Sextus Empiricus." Oxford Studies in Ancient Philosophy 56 (2019).

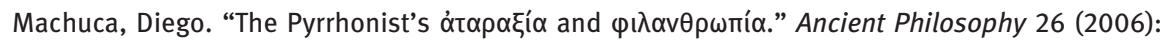
111-39.

Mackie, John Leslie. Ethics: Investing Right and Wrong. Harmondsworth: Penguin, 1977.

Mates, Benson. The Skeptic Way: Sextus Empiricus's Outlines of Pyrrhonism. New York: Oxford University Press, 1996.

McPherran, Mark. "Ataraxia and Eudaimonia in Ancient Pyrrhonism: Is the Skeptic Really Happy?" Proceedings of the Boston Area Colloquium in Ancient Philosophy 5 (1989): 135-71.

Naya, Emmanuel. "Traduire les Hypotyposes pyrrhoniennes: Henri Estienne entre la fièvre quarte et la folie chrétienne." In Le scepticisme au XVI et au XVII', edited by Pierre-François Moreau, 48-101. Paris: Albin Michel, 2001.

Nussbaum, Martha. "Equilibrium: Scepticism and Immersion in Political Deliberation." In Ancient Scepticism and the Sceptical Tradition (Acta Philosophica Fennica 66), edited by Juha Sihvola, 171-97. Helsinki: Societas Philosophica Fennica, 2000.

Nussbaum, Martha. "Skeptic Purgatives: Disturbance and the Life without Belief." In Nussbaum, The Therapy of Desire: Theory and Practice in Hellenistic Ethics, 280-315. Princeton: Princeton University Press, 1994.

Nussbaum, Martha. "Skepticism about Practical Reason in Literature and the Law." Harvard Law Review 107 (1994): 714-44.

Obdrzalek, Suzanne. "From Skepticism to Paralysis: The Apraxia Argument in Cicero's Academica." Ancient Philosophy 32 (2012): 369-92.

Perin, Casey. The Demands of Reason: An Essay on Pyrrhonian Scepticism. Oxford: Oxford University Press, 2010.

Spinelli, Emidio. "Neither Philosophy nor Politics? The Ancient Pyrrhonian Approach to Everyday Life." In Skepticism and Political Thought in the Seventeenth and Eighteenth Centuries, edited 
by John Christian Laursen and Gianni Paganini, 17-35. Toronto: University of Toronto Press, 2015.

Striker, Gisela. "Academics versus Pyrrhonists, Reconsidered." In The Cambridge Companion to Ancient Scepticism, edited by Richard Bett, 195-207. Cambridge: Cambridge University Press, 2010.

Striker, Gisela. "Historical Reflections on Classical Pyrrhonism and Neo-Pyrrhonism." In Pyrrhonian Skepticism, edited by Walter Sinnott-Armstrong, 13-24. New York: Oxford University Press, 2004.

Vogt, Katja. "Scepticism and Action." In The Cambridge Companion to Ancient Scepticism, edited by Richard Bett, 165-80. Cambridge: Cambridge University Press, 2010.

Wheatley, Thalia and Jonathan Haidt. "Hypnotic Disgust Makes Moral Judgments More Severe." Psychological Science 16, no. 10 (October 2005): 780-84.

Wieland, Jan Willem. "Can Pyrrhonists Act Normally?" Philosophical Explorations 15, no. 3

(September 2012): 277-89. 